\title{
NASIONALISME DALAM PENDIDIKAN ISLAM
}

\section{Lukman Hakim}

Sekolah Tinggi Hukum Galunggung

Jl. Gunung Tugu Cipicung Cibaregbeg, Tasikmalaya Jawa Barat 46112

Email: lukmanhakim427@ymail.com

\begin{abstract}
ABSTRAK
Pembedaan antara santri (Islam) dengan nasionalis mulai menghangat kembali. Hal ini dipicu oleh berbagai peristiwa tindakan kekerasan dan terorisme yang dilakukan sekelompok atau sebagian orang Muslim Indonesia yang berlatar belakang santri/pesantren. Dampaknya, masyarakat cenderung menganggap bahwa kini, santri (umat Islam) tidak lagi memiliki rasa cinta terhadap tanah airnya (nasionalisme). Tulisan ini bermaksud memberikan gambaran bahwa secara historis, umat Islam itu sebenarnya sangat nasionalis, khususnya pada zaman penjajahan Belanda. Beberapa pemberontakan dipelopori oleh kaum santri sebelum kaum nasionalis melakukannya, misalnya perang Diponegoro dan perang Banten. Studi terhadap upaya penggalian sikap nasionalis kaum santri ini didekati dengan studi tokoh. Tokoh yang diteliti adalah Abdul Wahab Khasbullah dan Ahmad Dahlan. Dengan mempelajari kedua tokoh nasional dan pendidikan Islam modern tersebut diharapkan umat Islam menyadari bahwa semangat mencintai tanah air/nasionalisme dan kebangsaan merupakan bagian yang tak terpisahkan dari doktrin ibadah umat Islam.
\end{abstract}

Kata kunci: Pembaharu, NU, Pendidikan Islam, Nasionalisme

\section{ABSTRACT}

The distinction between santri (Islam) and nationalist became the burning issue again. This is triggered by the acts of violence and terrorism done by a group/some Indonesian Muslims who have backgrounds as santri in pesantren. As a result, people tend to consider that santri (Muslims) no longer has a love for his homeland (nationalism). This paper intends to provide an overview that historically, Islam was actually very nationalistic, particularly in the Dutch colonial times. Many rebellions came previously from Santri before the nationalists do, such as Diponegoro war and Banten war. The studies of nationalist attitude of the santri was approached with character studies. In addition, figures of the study were Abdul Hasbullah and Ahmad Dablan. By studying both national modern and Islamic education figures, it is expected that Muslims realize the spirit of loving their motherland as well as the nationalism as the part of religious doctrine of Muslims.

Keywords: Reformer, NU, Islamic education, Nationalism 


\section{PENDAHULUAN}

Saat ini, umat Islam Indonesia sedang menghadapi ujian berat atas rasa nasionalisme kebangsaannya. Hal ini berhubungan erat dengan maraknya berbagai tindakan terorisme yang dilakukan sebagian kelompok radikal Islam. Perilaku teror, radikal dan anarkis yang ditampilkan oleh sebagian umat Islam menimbulkan pertanyaan serius mengenai tingkat rasa bangga umat Islam Indonesia terhadap bangsa dan negaranya. Padahal secara historis, tokoh-tokoh Islam masa lalu telah meletakkan dasar-dasar nasionalisme kebangsaan di bumi Nusantara ini dengan mendirikan beragam lembaga pendidikan Islam seperti pesantren dan madrasah. Ironisnya, kini, justru pesantren itulah yang dituding sebagai sarang terorisme dan gerakan radikal lainnya. Gerakan radikalisme Islam atau dakwah Islam dengan kekerasan mengesankan seolah-olah Islam di Indonesia sudah tidak lagi menjunjung tinggi nilai-nilai kebangsaan yang santun, ramah, dan mencintai perdamaian. Padahal, pada masa lalu para tokoh pembaruan Islam sudah membuktikan betapa tinggi rasa nasionalis mereka dalam membela bangsa dan Negara Indonesia. Pada tahun 1970-an, para cendekiawan Muslim sudah berusaha merekatkan kembali Islam dengan keindonesiaan. Salah satu usahanya dengan mencoba menggali kembali akar-akar nasionalisme awal Indonesia dalam mengusir penjajah di bumi Nusantara ini. Islam dan keindonesiaan merupakan suatu formula untuk menjadikan umat Islam sebagai warga negara yang memiliki rasa cinta tanah air dan keinginan yang sama untuk memajukan bangsa ini, tanpa ada stigma negatif atas perjuangan umat Islam di tanah air ini.

Memahami umat Islam sebagai bagian dari kesadaran akan rasa nasionalisme merupakan usaha merekatkan kembali akar kesejarahan Islam di masa lalu. Islam sebagai bagian dari kebangkitan nasional Indonesia akan mampu membuka sekat-sekat dikotomi yang selama ini kerap mengganggu kerukunan antarwarga negara Indonesia, khususnya bila dikaitkan dengan perbedaan antara umat Islam dan kelompok nasionalis. Konsep "umat" dalam Bahasa Arab bermakna bangsa/nation/people. Tetapi di Indonesia, konsep umat lebih berkonotasi politis, karena maknanya lebih melekat pada orang-orang yang menerima kehendak Ilahi sebagaimana yang terekspresikan dalam syariah. Selanjutnya menimbulkan kebutuhan akan institusi-institusi untuk memberlakukan hukum/sistem syariah tersebut. Dengan demikian konsep umat di Indonesia lebih bermakna sebagai komunitas politik Islam (Greg Fealey, 1997: 90).

Walaupun wacana perbedaan nasionalis-Islamis tidak menimbulkan perpecahan dan disintegrasi, tetapi gema dikotomis antara Allahu Akbar dan "Merdeka" mengingatkan kita kembali pada perdebatan dalam rapat konstituante antara fraksi Islam dengan fraksi nasionalis tentang pemberlakuan syariat Islam (Ma'arif, 1985). Ungkapan kelompok nasionalis yang identik dengan "Merdeka" dan kelompok Islam yang identik dengan Allabu Akbar berasal dari pidato Hasyim Muzadi, ketua PB NU ketika mendeklarasikan pencalonan Mega-Hasyim 
sebagai calon presiden dan wakil presiden dari PDIP. Hasyim Muzadi mengatakan pasangan ini (Mega-Hasyim) dapat mempersatukan nasionalis dan religius. Cak Nur mengatakan bahwa tidak ada lagi dikotomi antara nasionalis dan religius (santri). Jika ada maka dikotomi ini cenderung menyesatkan (Republika, 2004: 1). Pernyataan politis tersebut kerap menjadikan kelompok Islam dalam konteks pergaulan ke-Indonesia-an sering terpojokan. Dalam kurun waktu lima puluh tahun, nuansa pembedaan Islam dan nasionalis masih dapat dirasakan.

Tulisan ini bermaksud menguraikan pandangan para pembaharu pendidikan Islam Indonesia yang dimotori oleh K.H. Ahmad Dahlan dan K.H. Abdul Wahab Khasbullah tentang cita rasa kebangsaan dan usaha mereka dalam meraih cita-cita kemerdekaan Indonesia. Penelusuran sistematis dan historis atas pandangan hidup keduanya merupakan usaha untuk menyingkap betapa nasionalisnya umat Islam Indonesia pada masa itu dan betapa ajaran-ajaran Islam senantiasa menanamkan secara kuat tentang pentingya rasa cinta terhadap tanah airnya. Penanaman rasa kebangsaan dan cinta tanah air, dalam pelaksanaannya berhubungan erat dengan gerakan pembaruan pendidikan Islam Indonesia saat itu. Memajukan pendidikan sama dengan memajukan bangsanya dari keterbelakangan dan kebodohan menjadi cendikia dan terpelajar sehingga dapat sejajar dengan bangsa-bangsa lain di dunia. Prasangka bahwa umat Islam itu dianggap tidak nasionalis karena selalu memiliki agenda tersembunyi untuk mendirikan negara Islam tidak mewakili aspirasi seluruh umat Islam Indonesia, sebab kehidupan kedua tokoh perjuangan dan pendidikan Islam di atas senantiasa dilandasi cita-cita luhur kemerdekaan Indonesia yaitu mencerdaskan kehidupan bangsa dan ikut melaksanakan ketertiban dunia.

\section{PEMBAHASAN}

Jauh sebelum gerakan kemerdekaan dan kebangkitan nasional melalui Jong Java, Jong Selebes, yakni pada abad ke-17-18, Islam sebagai entitas kekuasaan dan budaya Nusantara telah menunjukkan sumbangsih yang mengagumkan. Nuruddin al-Raniri, Abdul Rauf al-Sinkili, dan Muhammad Yusuf al-Makassari (Azra, 1998: 166-307) adalah sebagian nama pembawa corak pemikiran dan praktik keagamaan yang memengaruhi warna dan produk para ulama pembawa ajaran Islam di Indonesia. Setelah Islam mengakar kuat, muncullah pesantren, madrasah dan sekolah Islam lain yang menandai produk keragaman lembaga pendidikan Islam Indonesia.

Madrasah Nizhamiyah di Baghdad merupakan lembaga pendidikan Islam formal yang resmi didirikan oleh pemerintah Irak (Maksum, 1999: 61). Ia merupakan lembaga pendidikan Islam pertama di dunia. Pendirian madrasah ini selain didorong oleh motivasi menyebarkan agama Islam, meningkatkan kesejahteraan ekonomi (tenaga-kerja), juga dilandasi oleh motivasi politikpengembangan aliran pemikiran Islam. Ia membawa aliran pemikiran Islam 
tertentu. Ia mencontoh sistem Nizhamiyah milik Mu'tazilah, Ikhwanul Safa, ahli filsafat, ahli sufi dan ahli figh.

Model madrasah Nizhamiyah yang Timur Tengah minded dianggap terlalu modern untuk ukuran Indonesia saat itu sehingga sebagai bentuk lembaga pendidikan Islam dipandang kurang efektif karena dirasa asing oleh bangsa Indonesia. Sejak awal abad 16, ia kemudian "dilokalkan" menjadi pesantren, dayah atau surau (Dhofier, 1997: 31-37). Surau adalah sebutan pesantren di Minangkabau yang ditinggali anak-anak muda sebagai tempat belajar mengaji alQur'an, belajar agama, tempat upacara-upacara yang berkaitan dengan agama Islam (Azra, 2003: 9). Mereka mengambil dasar dari lembaga padepokan yang sebelumnya telah dikenal di Nusantara. Karena mirip dengan padepokan inilah, para antropolog klasik, seperti Steenbrink dan Deliar Noer memandang bahwa pesantren/dayah/surau merupakan lembaga pendidikan Islam tradisional.

Proses dialog antara pendidikan Islam tradisional dengan pendidikan Barat ditandai dengan didirikannnya sekolah Barat pada masa VOC tahun 1632. Saat itu di Ambon telah ada sejumlah sekolah dan pada tahun 1675 tercatat ada 33 sekolah (Daulay, 2001: 36). Terlebih ketika didirikan Hollansche Inlandsche School (HIS), Meer Unitgebreid Lager Ondanwijs (MULO), Hoorgeie Burger School (HBS) dan Algeemene Middlbrate School (AMS), sekolah yang setara dengan SMA pada masa sekarang, menjadikan pendidikan Islam juga harus berupaya memodernisasi diri (Daulay, 2001: 91-92). Dalam beberapa hal lembaga pendidikan Islam yang ada mengadopsi beberapa bentuk pendidikan Barat seperti dengan adanya kelas, kurikulum, penjenjangan usia, seragam dan tempat duduk. Salah satu penggagas modernisasi sekolah keagamaan adalah Ahmad Dahlan (1868-1923). Ia mengadopsi sistem pendidikan Barat pada sekolah agama yang didirikannya (Shihab, 1998: 116).

Pembaruan pendidikan Islam tidak identik dengan westernisasi. Pembaruan pendidikan Islam utamanya adalah pola pikir para penyelenggara pendidikan Islam, seperti mengubah cara pandang mereka terhadap hubungan penjajah dengan pribumi. Dengan demikian ada sejumlah alasan yang menyebabkan pembaruan pendidikan Islam Indoneisa saat itu dan hingga kini perlu dilakukan, yaitu;

Pertama, pembaruan pendidikan Islam di Indonesia dimulai dari kegelisahan banyak tokoh pendidikan Islam terhadap kaum Muslimin yang sangat terbelakang, khususnya di bidang pendidikan dan kebudayaan. Wawasan intelektual mereka nampak semakin sempit dan mata pelajaran hanya terfokus pada masalah teologi. Kegelisahan ini muncul atas inspirasi dari pertemuan para pembaharu pendidikan Islam dunia seperti Muhammad Ali Pasha, al-Tahtawi, Jamaludddin al-Afghani, Muhammad Abduh, Rasyid Ridha dan Sir Ahmad Khandi Universitas Al-Azhar, Kairo, Mesir. Mereka menghasilkan sepakat bahwa pendidikan Islam di seluruh dunia harus dimodernisasi secepatnya jika tidak ingin terus tertinggal oleh umat lain (Azra, 2002: 25-26). 
Kedua, pembaruan pendidikan Islam penting dilakukan sebab muncul beberapa masalah dikotomis antara sekolah formal dengan sekolah non/informal. Sekolah formal pada masa kolonial Belanda adalah sekolah bentukan pemerintah Belanda dan didukung sepenuhnya oleh pemerintah Hindia Belanda. Kecuali sekolah formal, terdapat pesantren, dayah, surau dan nggon ngaji yang didirikan oleh masyarakat pribumi dan kurang didukung oleh pemerintah Hindia Belanda. Hal ini terjadi karena pesantren dan sejenisnya ini kerap kali mengkritik kebijakan pemerintah Hindia Belanda dan dianggap kurang bermartabat karena tempat belajar mereka yang tersebar di rumah-rumah penduduk/tokoh masyarakat. Namun demikian santri dan muridnya cukup banyak dan mereka serius mempelajari al-Qur'an dan kitab-kitab ke-Islam-an lain (Dhofier, 1992: 88).

Dalam perkembangan selanjutnya muncul dikotomi antara sekolah formal yang hanya mengajarkan pendidikan umum, sementara sekolah non/in-formal yang hanya mengajarkan pendidikan agama Islam. Hal ini menyebabkan terjadinya perbedaan orientasi pengembangan keilmuan yang berakibat terjadinya perbedaan mutu lulusan. Para santri yang belajar di sekolah non/in-formal tidak akan mampu menyaingi kaum abangan yang biasanya sekolah di sekolah formal/umum. Pekerjaan pegawai pemerintahan hindia Belanda dan antekanteknya didominasi kelompok bangsawan Jawa/priai. Sementara santri tidak memiliki akses seperti mereka. Akan tetapi kondisi tersebut menyebabkan jelasnya posisi santri sebagai pejuang kemerdekaan. Dalam konteks akademis pembedaan santri, abangan dan priai hanya pemilahan varian agar memudahkan studi tentangnya dan boleh jadi, secara keilmuan pembedaan tersebut sudah ketinggalan zaman (Van Neil, 1984: 75 dan Geertz, 1976). Menyikapi masalah tersebut, Hasan pada tahun 1930-an, mengeluhkan; "Apa boleh buat, di zaman dan di negeri ini, belajar bahasa Arab, tidak dapat membuatnya menjadi pegawai" (Steenbrink, 1994:195).

Ketiga, pendidikan Barat yang cenderung mempelajari dan mengembangkan ilmu Barat sebetulnya tidak bersifat netral. Pendidikan Barat yang diselenggarakan oleh pihak zending dalam permulaan abad ke-19 sarat dengan misi penginjilan dan/atau kristenisasi lewat sekolah formal. JA. Van Der Chijs melaporkan perjalanan pendidikan di Maluku tahun 1867, bahwa guru-guru dari Belanda selain sebagai guru sekolah juga berprofesi sebagai pendeta. Dalam hal ini, pemerintah kolonial Hindia-Belanda berperan penting dalam melakukan penetrasi agama Kristen dan/atau Katolik di tanah jajahan. Karena itu, pemerintah Hinda-Belanda dan antek-anteknya oleh kaum pribumi di cap kafir dan perlu dilawan (Steenbrink, 1987: 159-160 dan Suminto, 1996: 9-38).

Keempat, adanya dialog antara tokoh-tokoh pembaruan pendidikan Islam dengan tokoh-tokoh nasionalis sekuler maupun nasionalis religius. Salah satu tokoh penggerak dialog tersebut adalah Kyai Haji Wahab Khasbullah, pendiri dan pengasuh Pondok Pesantren Tambak Beras Jombang Jawa Timur (wafat 1971). Ia salah seorang pendiri Nabdlatul Ulama (NU) yang di tahun 1914 
mendirikan kelompok diskusi Tashwirul Afkâr dan menjalin kedekatan dengan Dr. Sutomo (nasionalis) melalui kelompok diskusi Islamic Studies Club. Kelompok diskusi ini memberi kontribusi kepada percepatan pertumbuhan rasa solidaritas antara kelompok nasionalis dengan religius (Zuhri, 1983: 40). Dari kalangan nasional religius dipelopori oleh Kyai haji Ahmad Dahlan. Dengan organisasi Muhammadiyah yang didirikannya ia menjalin kedekatan dengan para pemimpin Syarikat Islam (SI) yang tidak mau kooperatif dengan penjajah (Jainuri, 2002: 139-147). Dari pertemuan tersebut mereka punya cita-cita untuk secara bersamasama memerdekakan Bangsa Indonesia dari penjajah. Kerjasama mereka dimulai dengan membangun dan mengembangkan pendidikan, baik pendidikan agama maupun pendidikan umum.

\section{Pendidikan Islam Masa Belanda}

Pada masa pemerintahan Kolonial Belanda, pendirian sekolah-sekolah Islam di Nusantara tidak selamanya berjalan mulus bahkan lebih banyak menghadapi jalan yang terjal. Hal ini diakibatkan oleh tindakan Kolonial Belanda yang menekan sekolah-sekolah Islam yang selalu kritis menentang kebijakan imperial mereka, walaupun tidak selalu dengan melakukan perlawanan fisik. Pemerintah Belanda membatasi pendirian pesantren dan harus melaporkan setiap ada pesantren baru, tetapi tokoh-tokoh masyarakat pribumi tidak menggubrisnya bahkan pondok pesantren semakin banyak didirikan baik di pinggir kota atau di pelosok desa. Hal ini memperlihatkan bahwa para tokoh pendidikan Islam tidak mau berkompromi dengan kekuasaan Belanda baik yang ada di kota maupun di desa. Sebagai manusia, mereka tidak mau diatur oleh penjajah terutama jika berurusan dengan agama. Pendirian pesantren dan lembaga pendidikan Islam lain adalah urusan agama bukan semata-mata ekonomi atau politik. Lama-kelamaan keyakinan ini berubah menjadi doktrin Islam bahwa segala bentuk kerjasama dengan kaum kafir yang harus ditolak oleh kaum Muslimin. Hal ini mengindikasikan timbulnya perlawanan sekolah-sekolah Islam terhadap penjajah dan baik secara langsung atau tidak menumbuhkan rasa cinta tanah air dan bangsa yang tinggi. Akan tetapi justru menimbulkan ketegangan. Ketegangan ini menjadikan sekolah menjadi sulit didirikan di Nusantara. Puncak ketegangan antara pendidikan kolonial Belanda dengan pendidikan Islam adalah adanya kebijakan kolonial Belanda tentang ordonansi guru (Wilde School Ordonantie).

Pemerintah kolonial Belanda mengatur sedemikian rupa bahwa semua guru agama Islam yang akan mengajar di suatu sekolah wajib memperoleh surat izin mengajar yang dikeluarkan oleh pemerintah kolonial (Daya, 1995: 262). Pengawasan berlebihan dari pemerintah kolonial Belanda menimbulkan perlawanan dan pemberontakan dari kaum Muslimin. Pemerintah kolonial Belanda semakin bersikap tidak netral terhadap agama Islam. Hal ini dinyatakan dalam pasal 199 Konstitusi Belanda tahun 1885 (Shihab, 1998: 197). Puncaknya adalah terjadi pemberontakan petani di Cilegon, Banten (Jawa Barat) pada tahun 
1888 yang dimotori oleh guru-guru agama Islam (Morgan, 1958: 47-79). Ini adalah dampak misi pemerintah kolonial Belanda untuk memperluas pengaruh Kristen dan membatasi pengaruh Islam.

Dalam hak actroi VOC (Belanda Swasta) terdapat satu pasal yang berbunyi bahwa badan ini harus berniaga di Hindia Belanda dan bila perlu boleh berperang. VOC pun harus memperhatikan agama Kristen dengan mendirikan sekolah. Saat Van Den Boss menjabat sebagai Gubernur Jenderal Hindia Belanda di Batavia tahun 1831 ditetapkan kebijakan bahwa sekolah gereja dianggap sebagai sekolah pemerintah. Di luar sekolah gereja dianggap bukan sekolah resmi. Dampaknya pondok pesantren, masjid, mushalla dan surau dianggap tidak membantu pemerintah Belanda. Para santri masih dianggap buta huruf Latin. Madrasah dan pesantren dianggap tidak berguna karena dianggap tidak sesuai dengan "rumah tangga desa". "Sekolah desa" didirikan dalam rangka menandingi madrasah, pesantren, atau pengajian yang ada di desa (Zuhairini, 2008: 148-149).

Tahun 1882, pemerintah Belanda membentuk badan khusus yang bertugas mengawasi pendidikan Islam yang disebut dengan Priesterraden. Orang yang mau mengajar ngaji rakyat harus meminta izin terlebih dahulu. Di sini nampak Belanda sudah mengalami ketakutan akan kemungkinan kebangkitan pribumi. Pada tahun 1925 pemerintah Belanda mengeluarkan peraturan yang lebih ketat lagi terhadap pendidikan agama Islam, yakni tidak semua orang (kiai) boleh memberikan pelajaran mengaji. Hal ini karena memberikan efek negatif terhadap kepentingan Kolonial Belanda, pada saat yang sama organisasi pendidikan Islam sudah terlalu tumbuh dan berkembang. Muhammadiyah, Partai Syarikat Islam, Al-Irsyad, dan Nabdlatul Wathan sudah banyak pengikutnya dan membuka cabang di mana-mana (Zuhairini, 2008: 149).

Meskipun peraturan pemerintah Belanda begitu ketat dan keras, pendidikan Islam Indonesia tidak kemudian lumpuh. Sebaliknya bahkan semakin tumbuh subur laksana jamur di musim hujan. Rupanya jiwa Islam tetap tertanam dan terpelihara dengan baik di dalam sanubari umatnya. Umat Islam Indonesia tidak surut karena ditakut-takuti dan tidak luntur karena dibujuk dan dipuji penjajah. Mereka hanya tahu bahwa mereka harus tetap berpegang pada tali agama, al-Qur'an dan hadis.

\section{Ahmad Dahlan}

Kiai Haji Ahmad Dahlan lahir pada tahun 1888 dari keluarga Muslim tradisional yang berdomisili di Kauman Yogyakarta. Ia anak Kiai Haji Sulaiman, khatib resmi Masjid Agung kesultanan Yogyakarta. Pada usia 22 tahun belajar di Mekah atas sponsor raja (1855-1916). Pembaharuan pendidikan yang dilakukannya sangat dipengaruhi oleh bacaan dan hubungannya dengan kaum Muslim modernis (Shihab, 1989: 109). Tahun 1903-1904 Ahmad Dahlan kembali menunaikan ibadah haji kedua kalinya. Di Jawa, ia menjadi santri kelana dan belajar pada Kiai Nawawi dari Banten, Kiai Mas Abdullah dari Surabaya, Kiai 
Fakih dari Kumambang Gresik (Mulkhan, 1990: 7). Ketika muda, ia memasuki anggota aktif Jam'iat Kheir (didirikan di Jakarta 17 Juli 1905). Ahmad Dahlan yang gemar mencari ilmu dan selalu haus akan informasi masuk ke Jam'iat Kheir dalam rangka menjalin hubungan dengan negara-negara Timur Tengah. Melalui organisasi tersebut ia dapat bersahabat dengan Ahmad Surkati, mentor Jamiat Kheir yang berasal dari Mesir (Saiman, 1995: 42). Hal yang paling mengilhaminya dalam mendirikan Muhammadiyah adalah keikutsertaan dirinya pada organisasi Budi Utomo dan Sarekat Islam.

Sejak usia muda, yaitu pada tahun 1908-1909, Ahmad Dahlan telah mendirikan sekolah, yakni Madrasah Ibtidaiyah (SD) dan Madrasah Diniyyah di rumahnya. Sekolah ini dikelola secara modern dengan menggunakan metode dan kurikulum baru antara lain diajarkan berbagai ilmu pengetahuan umum yang sedang berkembang abad 20, juga penggunaan kursi, bangku serta kelas yang pada waktu itu masih dianggap asing (Mulkan, 1999: 19).

Ia sangat terkesan dengan model pendidikan kolonial Belanda. Akhirnya, ia merancang pendidikan Islam model sekolah kolonial, di mana ada penjenjangan kelas, kurikulum yang jelas, dan adanya seragam sekolah. Ahmad Dahlan adalah seorang Muslim yang senantiasa berpikir logis/rasional. Akal dan ilmu adalah dua hal yang selalu dikedepankan Ahmad Dahlan dalam mengerjakan sesuatu (Mulkan, 2003: 9-95). Sebagai guru di sekolah Islam, Ahmad Dahlan menjadikan al-Qur'an sebagai dasar (Shihab, 1998: 113). Hal ini meniru model Sekolah Dasar Belanda yang mewajibkan murid mempelajari Injil dan Bibel. Bagi Ahmad Dahlan, ini ijtihad yang didasarkan oleh realitas sosial yang selalu berkembang dan cenderung membawa manfaat. Ahmad Dahlan memajukan pendidikan Islam adalah memperbaiki sistem pendidikan Islam yang dualistis, yaitu memisahkan antara ilmu agama dan ilmu pengetahuan umum dengan cara menyatukan sistem pendidikan Barat yang lebih mengutamakan dan mengembangkan aspek intelektual dengan sistem pendidikan Islam yang kurang mengembangkan aspek intelektual. Dari sepak terjangnya dapat dipahami bahwa Ahmad Dahlan terpengaruh pemikiran Muhammad Abduh (Lubis, 1995: 102).

Tahun 1912 di Yogyakarta, Ahmad Dahlan mendirikan Muhammadiyah, sebuah organisasi yang berupaya memberikan kesejahteraan sosial dan mengembangkan pendidikan modern-Islam. Ahmad Dahlan banyak bergaul dengan kelompok Islam kota, maka model pendidikan Muhammadiyah juga dipengaruhi kultur kekotaan saat itu yaitu tidak terlalu alergi dengan Belanda sambil tetap menyebarkan pengajaran Kanjeng Nabi Muhammad SAW kepada penduduk bumi putera dan memajukan kehidupan anggota-anggotanya dalam kerangka agama Islam. Selain mendirikan lembaga pendidikan Islam, Ia kerap kali mengadakan pertemuan, pengajian dan tabligh untuk membicarakan dan memecahkan masalah-masalah Islam, membangun masjid, mendirikan lembaga wakaf, menerbitkan buku, brosur, surat kabar dan majalah (Noer, 1996: 86).

Melalui lembaga Muhammadiyah, pemikiran dan obsesi Ahmad Dahlan sedikit demi sedikit mulai terlaksana dan membuahkan hasil. Banyak masyarakat 
yang mulai tertarik untuk mengikuti kegiatannya. Aspek organisasi Muhammadiyah yang menjadi organisasi legal, karena mendapat izin dari Gubernur Jenderal Belanda, menjadikan Muhammadiyah lebih luwes bergerak, khususnya dalam memajukan kehidupan sosial, ekonomi dan pendidikan seluruh anggotanya. Muhammadiyah menjadi organisasi pendidikan yang kooperatif dengan kolonial Belanda. Belanda menganggap bahwa Muhammadiyah tidak bersentuhan dengan politik praktis (Shihab, 1998: 115).

Walaupun Muhammadiyah menjauhi kegiatan politik tetapi tidak berarti Ahmad Dahlan dan Muhammadiyah tidak berpolitik. Pribadi Ahmad Dahlan yang sangat terbuka dengan ide-ide orang lain menjadikan Ahmad Dahlan mudah bergaul dengan banyak orang. Ahmad Dahlan menginginkan dan kaum Muslimin untuk senantiasa memiliki wawasan yang luas. Ia menyarankan kepada seluruh anggotanya untuk mempelajari agama dan gagasan orang lain. Ia yakin bahwa kebenaran berdasarkan wawasan yang lebih luas ini akan memberikan dukungan yang lebih besar bagi implementasi agama Islam dalam kehidupan seseorang atau seluruh orang (Jainuri, 2002: 113).

Bagi Ahmad Dahlan, untuk mencari kebenaran, orang tidak boleh merasa benar sendiri. Karena itu, orang harus berani berdialog dan diskusi dengan semua pihak, walaupun dengan orang atau golongan yang bertentangan dan berbeda pendapat (Mulkan, 1998: 11). Dengan sifat yang terbuka ini menjadikan Ahmad Dahlan dan Muhammadiyah menjadi rujukan kelompok nasionalis ataupun komunis untuk menuangkan gagasan-gagasan mereka tentang kemerdekaan Indonesia. Sifat terbuka ini tercermin dari kesediaan Ahmad Dahlan menerima tawaran pemimpin Indische Social Democratische Party (ISDV) untuk berbicara di hadapan Aisyiyah, sebuah organisasi perempuan di bawah Muhammadiyah (Rahardjo, 1999: 234). Organisasi ini didirikan di Semarang oleh Ir. Adolf Baars pada bulan Mei 1914. ISDV adalah partai yang berideologi komunis. Tetapi orang yang paling berjasa memperkenalkan komunis di Indonesia adalah HJFM Sneevliet yang datang ke Jawa tahun 1913 dan pernah menjadi pemimpin redaksi harian Soerabajasch Handelsblad (Rahardjo, 1999: 234).

Walaupun keputusan ini banyak mendapat protes dari para anggota Muhammadiyah, tetapi bagi Ahmad Dahlan, pertemuan itu merupakan pembelajaran bagi kader Muhammadiyah dalam menerima gagasan orang lain. Kader Muhammadiyah mengatakan bahwa ideologi Islam merupakan pilihan yang lebih baik bagi perjuangan kemerdekaan dibandingkan komunisme (Rahardjo, 1999: 234). Pemahaman ini diperoleh bukan atas dasar prasangka tetapi atas dasar telaah dan analisa yang cermat. Terbukti bahwa hingga kini komunisme tidak mendapat tempat di hati rakyat Indonesia. Hasil kerja dan pemikiran Ahmad Dahlan dalam menerima dan membuka pintu organisasinya terhadap dunia luar, terutama organisasi yang pro-kemerdekaan menjadikan salah seorang anggota Muhammadiyah, Fahruddin (lahir 1889) menjadi 
wartawan di koran "Islam Bergerak" terbitan ISDV. Koran ini diasuh oleh Haji Misbach, yang seorang Muslim-Komunis (Alfian, 1994: 200-204).

Perjumpaan Ahmad Dahlan dengan pemimpin Sarekat Islam (SI) semakin memicu rasa nasionalis Ahmad Dahlan. Sarekat Islam (berdiri 1911) adalah kelanjutan dari organisasi Sarekat Dagang Islam (1905) yang didirikan oleh Haji Samanhudi di Solo. Sarekat Islam yang kemudian dipimpin oleh Cokroaminoto memandang positif akan ajaran Islam. Bagi Sarekat Islam, agama Islam adalah kemajuan (Alfian, 1994: 47).

Walaupun dia telah mendirikan Muhammadiyah (1912), ia tetap menjadi penasehat SI (1914-1917). Ide-ide nasionalisme untuk mencapai kemerdekaan Indonesia mulai tertanam kuat dalam sosok Ahmad Dahlan. Ahmad Dahlan kemudian memutuskan bahwa anggota Muhammadiyah yang mendukung kemerdekaan Indonesia dapat menyalurkan aspirasinya melalui SI tanpa mengorbankan Muhammadiyah yang tetap pada jalur sosial dan pendidikan.

Komitmen Ahmad Dahlan untuk kemerdekaan Indonesia tercatat dalam perjanjian tahun 1920 antara SI dengan Muhammadiyah. SI membuat komitmen untuk berjuang dalam politik sementara Muhammadiyah memilih berkonsentrasi dan berjuang lewat lapangan agama, pendidikan, dan sosial (Jainuri, 2002: 144). Komitmen untuk berjuang dengan SI ini terlihat dari usaha Muhammadiyah mendirikan sekolah yang menyaingi Sekolah Gubermen (milik Belanda) yang merupakan cita-cita SI sejak lama.

Di samping mendirikan sekolah yang mengikuti model Gubermen, Muhammadiyah dalam waktu singkat juga mendirikan sekolah yang bersifat agama. Sekolah ini, seperti Madrasah Diniyyah di Minangkabau yang dimaksudkan untuk memperbaiki dan mengembangkan model pengajian alQur'an yang lebih modern. Untuk pengajian kitab, Muhammadiyah juga segera mencari penggantinya yang sesuai dengan tuntutan zaman modern, usaha tersebut dapat dianggap sebagai realisasi dari rencana Sarekat Islam yang semenjak 1912 berusaha mendirikan sekolah pendidikan agama, yang dapat menyaingi sekolah pendidikan guru gubernemen (Steenbrink, 1994: 104).

Sifat nasionalisme pada diri Ahmad Dahlan dan Muhammadiyah direfleksikan dalam lima fase ideologi Muhammadiyah ketika awal berdiri. Lima fase ini yaitu: rasionalisme, pendidikan sebagai landasan bagi pembangunan politik, pengaruh keanggotaan kelas menengah, minat kepada budaya Jawa, dan sikap yang bermusuhan terhadap doktrin-doktrin asing, seperti komunisme dan Kristen (Shihab, 1998: 205).

Di masa kemerdekaan, pengakuan atas jasa Ahmad Dahlan dalam usaha menuju kemerdekaan Indonesia diwujudkan dengan pemberian anugerah sebagai Pahlawan Nasional. Dalam pidato pembukaan Muktamar Muhammadiyah ke-41 di Solo, Jawa Tengah tahun 1985 Presiden Soeharto mengomentari atas usaha Muhammadiyah dalam membantu perjuangan Nasional Indonesia. Benih-benih semangat kebangsaan langsung atau tidak langsung mulai ditaburkan oleh 
pemimpin-pemimpin dan pemuka Muhammadiyah ke dalam sanubari rakyat Indonesia (Saiman, 1995: 56).

\section{Abdul Wahab Khasbullah}

Tokoh pembaruan pendidikan Islam lain khususnya di lingkungan pesantren adalah Abdul Wahab Khasbullah (1888-1971). Ia berjasa dalam mendorong pesantren untuk senantiasa bersikap menerima dan mencoba melakukan reformasi. Ia menguatkan posisi tawar kelompok Islam-pesantren dengan membentuk organisasi Nabdlatul Ulama. Van Bruinesen menyebut Wahab Khasbullah sebagai pendiri NU yang sebenarnya. Hasyim Asy'ari sebagai pendiri NU lebih berperan sebagai yang memberi restu. Proses pendirian NU yang berliku-liku dapat diatasi berkat peran Wahab Khasbullah (Van Bruinsen, 1994: 46).

Sebelum Abdul Wahab Khasbullah diwarisi pesantren Tambak Beras oleh ayahnya, Kiai Hasbullah, ia adalah seorang musafir pencari ilmu (santri pengelana). Sejak berumur 13 tahun ia sudah menimba ilmu kepada kiai-kiai besar di Nusantara (Dhofier, 1997: 25). Gambaran tersebut menunjukkan adanya tradisi kelana dalam pondok pesantren yang merupakan media pemersatu umat Islam Nusantara. Oleh karena itu, Abdul Wahab Khasbullah melakoni tradisi tersebut bukan dalam rangka berburu ilmu agama Islam semata, tetapi lebih jauh dari itu ia bermaksud menjalin silaturrahim dengan pesantren-pesantren di tanah Jawa. Dhofier menggambarkan alur perjalanan Abdul Wahab Khasbullah saat menjadi musafir bagaikan pendekar kelana. Setelah mendapat ilmu dari ayahnya, Hasbullah, pemimpin pesantren Tambak Beras, Jombang, Wahab Khasbullah melanjutkan ke Pesantren Pelangitan Tuban selama 1 tahun, Pesantren Mojosari di Nganjuk selama 4 tahun, ke Pesantren Tawangsari selama 1 tahun, Pesantren Kedemangan Bangkalan Madura, Pesantren Branggahan Kediri selama 1 tahun dan Pesantren Tebu Ireng, Jombang. Kemudian dilanjutkan ke Mekah selama 4 tahun dan berguru kepada enam ulama ternama, mereka adalah Kiai Mahfudz alTirmisy, Kiai Muhtaron, Syaikh Ahmad Khatib, Kiai Bakir, Kiai Asy'ari dan Syaikh Abdul Hamid (Dhofier, 1997: 25).

Pribadi Abdul Wahab Khasbullah yang merdeka dalam pergaulan dan vokal dalam berpendapat, mengantarkan dirinya untuk menjadi anggota Sarekat Islam yang dipimpin Cokroaminoto. Bahkan ketika di Mekah (1910-1914, Wahab Khasbullah, Ahmad Dahlan, Asnawi dan Abbas sempat mendirikan SI cabang Mekah walau tidak bisa direalisasikan karena keburu pulang ke Indonesia (Amin, 1996: 33). Ia juga aktif dalam kelompok diskusi intelektual nasional dengan ikut menjadi anggota Indonesiche Studie Club (ISC) pimpinan Dr. Sutomo (Anam, 1985: 31). Anggotanya biasanya adalah para aktivis pergerakan kemerdekaan. Karena itu, rasa cinta tanah air menjadi bahan perbincangan utama dalam ISC. Pergaulan seperti ini menjadikan Wahab Khasbullah sangat paham dengan masalah modernisasi, pembaruan pendidikan Islam dan 
nasionalisme (Amin, 1996: 28-29). ISC bukan hanya berdiri di Surabaya. Di Bandung ISC dibentuk oleh Sukarno (Rahardjo, 1999: 15).

Di ISC, Abdul Wahab Khasbullah mulai menggalang persatuan untuk usaha kemerdekaan Indonesia. Hal ini dilakukan dengan mempertemukan antara pemimpin-pemimpin pergerakan nasional dengan ulama untuk mengemukakan ide-idenya kemudian mengusahakan kesepahaman bersama di antara mereka yang saat itu renggang. Zuhri, mengemukakan bahwa cita-cita kebangsaan dan keindonesiaan Khasbullah semakin jelas saat ia menggalang aspirasi Islam dan Nasionalisme. Dua aspirasi ini adalah dasar untuk menggalang persatuan antara potensi Islam dan kaum nasionalis sebagai kekuatan pokok bangsa Indonesia dalam menghadapi politik kolonial Belanda. Hal ini terjadi pada tahun 1924-an. Pembentukan dasar strategi perlawanan pada kekuasaan kolonial yang dilakukan Khasbullah bukan tanpa resiko (Zuhri, 1983: 27). Golongan nasionalis dan kaum ulama sering tidak pernah bertemu baik dalam gagasan maupun tindakan. Hal ini menyebabkan Khasbullah sering dibenci baik oleh kalangan dari dua golongan tersebut maupun dari Belanda. Meski banyak berbeda pendapat, tetapi ada pula titik persamaannya yaitu antara Abdul Wahab Khasbullah dan golongan nasioalis sama-sama mempunyai keinginan untuk memerdekakan bangsa Indonesia dari penjajahan. Persamaan pandangan tentang keinginan memerdekakan diri dari penjajahan itu merupakan modal dasar kesepahaman antara kelompok nasionalis dan ulama-ulama yang berada di pesantren. Dengan adanya kesepahaman ini, proses gerakan kebangsaan berkolaborasi dalam perjuangan yang gigih untuk mengusir penjajah baik secara fisik maupun diplomasi.

Di Surabaya, bersama dengan Kiai Haji Mas Mansyur (tokoh Muhammadiyah), Khasbullah mendirikan Nabdlatul Wathan ${ }^{1}$ (kebangkitan tanah air), sebuah lembaga pendidikan bercorak nasional-moderat. Melalui Nabdlatul Wathan, Khasbullah mulai merealisasikan ide-idenya tentang pembaruan pendidikan Islam yang seiring dan sejalan dengan pendidikan kebangsaan dan perjuangan kemerdekaan Indonesia. Di sekolah Nabdlatul Wathan ini, ide-ide patriotiknya bersemi. Bahkan atas dasar kecintaannya pada kemerdekaan, Khasbullah menulis lagu berbahasa Arab yang dinyanyikan murid-muridnya sebelum pelajaran dimulai (Van Bruinsen, 1994: 46), jika di-Indonesiakan syair lagu tersebut berbunyi;

Wahai bangsaku, wahai bangsaku

Cinta tanah air bagian dari iman

Cintailah tanah air wahai bangsaku

Jangan kalian menjadi orang terjajah

(Amin, 1996: 31-32).

Sekolah Nabdlatul Wathan tidak hanya berdiri di Surabaya. Nabdlatul Wathan berdiri di banyak tempat, seperti Akblâqul Wathan di Semarang, Fa'ul Wathan di Gresik, Hidâyatul Wathan di Jember, Ablul Wathan di Wonokromo dan Khitâbul Wathan (Halim, tt: 34-35). Dengan berdirinya sekolah-sekolah ini, akar 
nasionalisme mulai disebarkan kepada para santri atau murid yang bersekolah di sana. Kesadaran akan rasa cinta tanah air tumbuh dalam ruang pendidikan sederhana yang diasuh oleh guru yang kebanyakan adalah santri-santri lulusan pesantren dan sekolah-sekolah Islam berjiwa nasionalis.

Sebelum konflik yang berkepanjangan antara "kelompok tradisionalis" dengan "kelompok modernis" berlangsung, ${ }^{2}$ Khasbullah mendirikan suatu kursus perdebatan/kelompok diskusi yang dinamakan Tashwîrul Afkêr. Melalui Tashwîrul Afkâr, Khasbullah mempertemukan pemuda Islam, ulama, baik dari kalangan "modernis" maupun "tradisionalis" untuk bersama-sama membahas keilmuan Islam, seperti madzhab dalam Islam, ijtihad dan masalah-masalah keislaman yang dibicarakan dengan sangat cair (Halim, tt: 34-35).

Melalui jalur pendidikan dengan mendirikan Nabdlatul Wathan dan Tashwîrul Afkâr, Wahab Khasbullah membangun semangat nasionalisme para ulama dan meningkatkan kapasitas intelektual para pemuda (Amin, 1996: 29-30). Semangat tersebut menginspirasi berdirinya NU yang berawal dari konflik antara kelompok Muslim modernis dan Muslim tradisionalis mengenai masalah Mekah yang dikuasai oleh kelompok Ibnu Saud yang beraliran Wahabi. Dalam konteks masalah Mekah, aliran Wahabi adalah aliran yang mengharamkan praktik-praktik keagamaan yang biasa dilakukan oleh kelompok tradisionalis (Ismail, 2002: 2324).

Wahab Khasbullah tetap menunjukkan jati dirinya sebagai seorang tokoh perubahan. Di Tambak Beras, ia mendirikan madrasah yang bernaung di bawah Pesantren Tambak Beras. Ide pendirian madrasah di lingkungan pesantren merupakan ide yang telah lama ia pikirkan. Pendirian madrasah di lingkungan pesantren bagi Wahab Khasbullah merupakan salah satu usaha memajukan pesantren agar tetap diterima dalam masa yang akan datang.

Sebagai seorang santri dan kiai, ide-ide Wahab Khasbullah yang mendirikan madrasah dan mendirikan jam'iyah NU mengindikasikan bahwa kelompok tradisionalis menjelma menjadi kelompok kebangkitan dalam dunia pendidikan Islam.

Consistent with its vision and mission, the Nabdlatul Ulama always attemted to carry out its program in social and religious fields. It established more madrasah and improved their management, aided the foundation of mosque, langgars (prayer houses) and pesantrens, and helped to prove for orphans the poor. In 1929, the Nahdlatul Ulama created an organization called Maarif Nabdlatul Ulama which served to coordinate and develop all educational institusions belonging to the Nabdlatul Ulama (Ismail, 2002: 37).

(Konsisten dengan visi misinya, Nabdlatul Ulama selalu mencoba meluaskan kegiatannya dalam wilayah sosial agama. Yaitu dengan mendirikan banyak madrasah dan memajukan sistem manajemen, membuat yayasan yang menaungi masjid, langgar, dan pesantren. Membantu meningkatkan kesejahteraan kaum miskin. Tahun 1929, 
Nabdlatul Ulama mendirikan organisasi termasuk Ma'arif yang bertugas mengkoordinasikan dan mengembangkan semua intitusi pendidikan yang dinaungi oleh Nahdlatul Ulama)

Ide-ide untuk kemerdekaan bangsa, pengorganisasian perjuangan, persatuan antara golongan Islam dan "nasionalis", perlawanan terhadap segala bentuk penjajahan, dan membangun potensi nasional untuk kepentingan seluruh bangsa (Zuhri, 1983: 106-107) tergambarkan dalam cita-cita mengentaskan kemiskinan sebagai nasib yang dialami bersama oleh bangsa. Nasionalisme adalah rasa cinta tanah air yang disertai kepedulian bersama untuk meningkatkan harkat dan martabat kehidupan rakyat yakni keadilan sosial bagi seluruh rakyat Indonesia.

\section{SIMPULAN}

Pembaruan pendidikan Islam disebabkan oleh dua hal besar yaitu; 1) adanya model pendidikan Barat yang menjadi pembanding bagi model pendidikan Islam Timur Tengah; 2) adanya kesamaan nasib sebagai bangsa terjajah dan terbelakang. Penyebab yang kedua merupakan berdampak ganda yakni bukan hanya sebagai pemicu pembaruan pendidikan Islam tetapi juga pemicu semangat kebangsaan dan jiwa nasionalis umat Islam. Ahmad Dahlan dan Abdul Wahab Khasbullah adalah dua tokoh pendidikan Islam sekaligus tokoh nasional yang mampu merespons situasi kolonial dengan cara mengobarkan semangat nasionalisme pendidikan yang dilandasi cita-cita kemerdekaan. Melalui pendidikan mereka berupaya mendidik dan menyadarkan anak bangsa untuk selalu sadar bahwa cita-cita untuk merdeka merupakan bagian dari semangat keberagamaan. Bagi mereka, nasionalisme juga harus dibangun dari kemandirian ekonomi bersama seluruh anak bangsa. Karena itu, cita-cita kemerdekaan pada dasarnya cita-cita mewujudkan kesejahteraan bersama secara berkeadilan. Mereka mencontohkan bahwa upaya meraih cita-cita mulia tersebut tidak harus dengan jalan politik praktis tetapi dapat melalui pendidikan.

\section{DAFTAR PUSTAKA}

Alfian.1994. Muhammadiyah; The Political of Moslem Modernist Organization Under Dutch Colonialism. Yogyakarta: Gajah Mada Press.

Amin, Mayhur. 1996. NU dan Ijtihad Politik Kenegaraannya. Yogyakarta: AL-Amin. Anam, Choirul. 1985. Pertumbuban dan Perkembangan Nabdlatul Ulama. Sala: Jatayu. Azra, Azyumardi. 1998. Jaringan Ulama: Timur Tengah dan Kepulauan Nusantara abad XVII dan XVIII. Bandung: Mizan.

, 2003. Surau; Pendidikan Islam: Tradisionalis dalam Transisi dan Modernisasi. Jakarta Logos Wacana Ilmu. 
2002. Pendidikan Islam; Tradisi dan Modernisasi Menuju Millenium Baru. Jakarta: Logos.

Van Bruinssen, Martin. 1994. NU, Tradisi, Relasi Kuasa, Pencarian Makna Baru. Yogyakarta: LkiS.

Daulay, Haidar Putra. 2001. Historisitas dan Eksistensi Pesantren, Sekolah dan Madrasah. Yogyakarta: Tiara Wacana.

Daya, Burhanudin. 1995. Gerakan Pembaharuan Pemikiran Islam; Kasus Sumatera Thawalib. Yogyakarta: Tiara Wacana.

Dhofier, Zamakhsayarie. 1997. Tradisi Pesantren; Studi tentang Pandangan Hidup Kiai. Jakarta: LP3ES.

-------, 1992. "Sekolah Al-Qur'an dan Pendidikan Al-Qur'an di Indonesia" dalam Ulumul Qur'an Volume III, No.4.

Fealey, Greg.(ed). 1997. Tradisionalisme Radikal: Persinggungan Nabdlatul Ulama dan Negara. Yogyakarta: LkiS.

Geertz, Clifford. 1976. The Religion of Java. Chicago: University of Chicago Press.

Halim, Abdul. tt. Sejarah Perjuangan Kiai Wahab Khasbullah. Bandung: PT Baru.

Ismail, Faisal. 2002. Islamic Tradisionalism in Indonesia; A Study of Nabdlatul Ulama. Jakarta: Litbang Depag.

Jainuri, Achmad. 2002. Ideologi Kaum Reformis; Melacak Pandangan Keagamaan Muhammadiyah Periode Awal. Surabaya: LPAM.

Lubis, Arbiyah. 1995. Pemikiran Mubammadiyah dan Mubammad Abduh.Jakarta: Bulan Bintang.

Ma'arif, Ahmad Syafii. 1985. "Islam dan Masalah Kenegaraan: Studi Tentang Percaturan dalam Konstituante". Jakarta: LP3ES.

Maksum. 1999. Madrasah Sejarah dan Perkembangannya. Jakarta: Logos.

Morgan, Kenneth W(ed). 1958. Islam the Straight Path; Islam Interpreted by Muslim. New York: The Ronald Press.

Mulkhan, Abdul Munir. 1990. Pemikiran K.H. Ahmad Dablan dan Muhammadiyah dalam Perspektif Perubahan Sosial. Jakarta: Bumi Aksara.

------, 2003. Nyufi Cara Baru; Kiai Abmad Dahlan dan Petani Modernis. Jakarta: Serambi Ilmu Semesta.

Noer, Deliar. 1996. Gerakan Modern Islam di Indonesia 1900-1942. Jakarta: LP3ES.

Rahardjo, Dawam. 1999. Intelektual Intelegensia dan Perilaku Politik Bangsa; Risalah Cendekiawan Muslim. Bandung: Mizan.

Republika, 2004, No. 119 tahun ke 12, Jumat, 7 Mei.

Saiman, Weinata. 1995. Gerakan Pembaruan Mubammadiyah. Jakarta: Pustaka Sinar Harapan.

Shihab, Alwi. 1998.Membendung Arus; Respon Gerakan Mubammadiyab Terbadap Penetrasi Misi Kristen di Indonesia. Bandung: Mizan.

Steenbrink Karel A. 1994. Pesantren, Madrasah dan Sekolah. Jakarta: LP3ES. , 1987. Beberapa Aspek Tentang islam di Indonesia Abad ke-19. Jakarta: Bulan Bintang.

Suminto, Aqib. 1996. Politik Islam Hindia Belanda. Jakarta: LP3ES. 
Zuhairini, dkk. 2008. Sejarah Pendidikan Islam. Jakarta: Bumi Aksara.

Zuhri, Saifuddin. 1983. Kiai W ahab Khasbullah Bapak dan Pendiri NU.Yogyakarta: Pustaka Falakiyah.

Syaifullah. tt. Gerakan Politik. Muhammadiyah Dalam Masyumi. Jakarta: Grafiti.

Zuhri, Syaifuddin. 1983. Kiai Haji Abdul Wahab Khasbullah Bapak dan Pendiri NU. Yogyakarta: Pustaka Falaakiyah.

${ }^{1}$ Ada dua pendapat mengenai model pendidikan apa yang didirikan oleh Wahab Khasbullah bersama K.H. M. Mas Mansyur. Zamakhsyari Dhofier dalam Tradisi Pesantren mengatakan hanya madrasah saja yang didirikannya (hal. 27) bahkan ada yang menyebut Nahdlatul Wathan adalah sebuah perkumpulan saja. Lihat dalam Syaifudin Zuhri, Kiai Haji, hlm. 25. tetapi penulis lebih setuju bahwa Wahab Khasbullah mendirikan sekolah Islam bernama Nahdlatul Wathan (kebangkitan tanah air) karena dalam tulisan Masyhur Amin, NU, dan Ijtibad, hlm.30 mencirikan sekolah ini adalah sebuah pendidikan formal, ada kursus politik, kepemimpinan, organisasi dan administrasi. Begitu juga dengan Faisal Ismail, Islamic Tradisionalism in Indonesia; A Study of Nabdlatul Ulama. (Jakarta: Litbang Depag, 2002), hlm. 30

2 Puncak konflik antara kelompok Muslim tradisionalis dan modernis adalah ketika Wahab Khasbullah membentuk komite Hijaz di Surabaya, 31 Januari 1926 yang akhirnya menjadi cikal bakal pembentukan NU. Dalam Martin van Bruinesen. NU, Tradisi, Relasi, Kuasa, hlm. 34. artinya Wahab Khasbullah mengambil posisi sebagai Muslim tradisionalis secara tegas. 